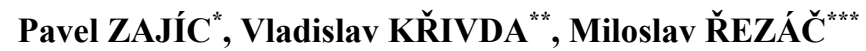 TRAFFIC CONFLICTS AS SAFETY INDICATOR - CURRENT STATE AND DEVELOPMENT
} DOPRAVNÍ KONFLIKTY JAKO UKAZATEL BEZPEČNOSTI - SOUČASNÝ STAV A VÝVOJ

\begin{abstract}
Traffic conflicts observed and recorded on the road represent a source of information for the most prevalent surrogate road safety indicators. In spite of the questions concerning their reliability and validity, this method stays on the threshold of further progress. Thanks to easier availability of more advanced information technologies and progress in stored data analysis methodology.
\end{abstract}

\begin{abstract}
Abstrakt
Dopravní konflikty zaznamenané ve skutečných provozních podmínkách jsou informačním zdrojem nejrozšiřrenějších nepřímých ukazatelů bezpečnosti silniční dopravy. Přes otázky spojené s jejich reliabilitou a validitou však tato metoda stojí na prahu dalšího rozvoje. Díky dostupnějším vyspělým informačním technologiím a pokroku v metodice hodnocení získaných dat.
\end{abstract}

\section{ACCIDENT DATA}

At the present, the road safety is still measured by the number of road traffic accidents and their consequences with respect to their severity. Although such approach (in literature called "historical") is useful for identifying specific problems of the location being evaluated, it is regarded as "reactive". It is assumed that a significant number of accidents must occur in order to identify a road safety problem that we can start solving with the use of adequate safety countermeasures. Another disadvantage of this approach is quality and availability of details of the accidents and time that is required for statistical evaluation of various measures implemented for the sake of safety improvement. In particular, with respect to the incidental character of their causes. Besides, occurrence of the accidents is a result of a chain of dynamic events, which are difficult to analyze merely based on the statistical data and mostly insufficiently documented records, which provide only few qualitative details related to the causes [4, page 7].

In order to conduct a more qualified and more complex form of the road safety analysis in specific locations of the traffic roads, it would be necessary to implement a faster and more costefficient measurement method, providing valid and reliable results without the need of the accident data, if possible. This alternative method of safety measurement could then provide the basis for modeling of predictions, which we could use to estimate the impacts on safety with acceptable statistical accuracy [4, page 7].

* Ing. Pavel ZAJÍC, VSB - Technical University of Ostrava, Faculty of Mechanical Engineering, Institute of Transport, 17. listopadu 15, Ostrava, tel. (+420) 722917 516, e-mail pavel.zajic@seznam.cz

** Ing. Vladislav KŘIVDA, Ph.D., VSB - Technical University of Ostrava, Faculty of Civil Engineering, Department of Transport Constructions, L. Podéště 1875/17, 70833 Ostrava-Poruba, tel. (+420) 59732 1315, e-mail vladislav.krivda@vsb.cz

*** doc. Miloslav ̌̌EZÁČ, Ing., Ph.D., VSB - Technical University of Ostrava, Faculty of Civil Engineering, Department of Transport Constructions, L. Podéště 1875/17, 70833 Ostrava-Poruba, tel. (+420) 59732 1313, e-mail miloslav.rezac@,vsb.cz 


\section{ENCROACHMENT SAFETY INDICATORS AS AN ALTERNATIVE}

The safety indicators, representing other type of measure for the road traffic evaluation, can be used as a more efficient alternative of traffic safety evaluation. These are characteristics of time and location of hazardous situations of encroaching vehicles ("near-accidents"). The main advantage of these indicators is their cost-effectiveness. The "near-accidents" (in other words, traffic conflicts) occur more often than the accidents. Therefore, they require shorter time of observation to provide statistically reliable results. These indicators are thus especially useful for the studies "before" and "after" implementation of traffic measures (such as in terms of organization or construction), completed in selected locations of the traffic road, the consequences of which we need to assess.

Another advantage of these indicators is that they respect interaction of all categories of the road users. Their methodology also makes provision for the safety aspects of the given location, as well as the complex relationships between the traffic variables, such as the average speed, traffic flows and maneuvers of the road users [4, page 7].

\section{TRAFFIC CONFLICT TECHNIQUE (TCT)}

The Traffic Conflict Technique (TCT) is a method of indirect road safety measurement. It is based on the ability to directly record (in normal operation and in real time) occurrence of conflict events (near-accidents). It, therefore, offers faster and in many aspects more characteristic method of estimating the expected frequency and occurrence of accidents [3].

The method was developed in the General Motors laboratories in Detroit at the end of the 1960 's for purposes of researching the safety problems in connection with designing the cars of this company [21]. It consisted in observing and recording the hazardous interactions between the road users, which required an evasive maneuver to avoid the threatened collision. The new method soon aroused the interest of researchers around the world, who recognized its potential and started to use it for seeking relations between conflicts and accidents.

This method was first improved in the United Kingdom, where they implemented the severity level evaluation [19]. The Czechoslovakia was the second country in Europe to implement the traffic conflict observation method on the initiative of Doc. Folprecht and in 1973 at the Road and Urban Transport Institute (ÚSMD) of Prague [8]. In 1988, Folprecht and Křivda incorporated this method based on the video-recording evaluation by trained observers in the lessons and research at the VSB-Technical University of Ostrava. The method is still successfully being used for solving numerous research tasks in the field of road safety evaluation, such as [8] and [13]. A similar method of traffic conflict observation based on their evaluation by direct observers on site is used at the Czech Technical University (CVUT) [20].
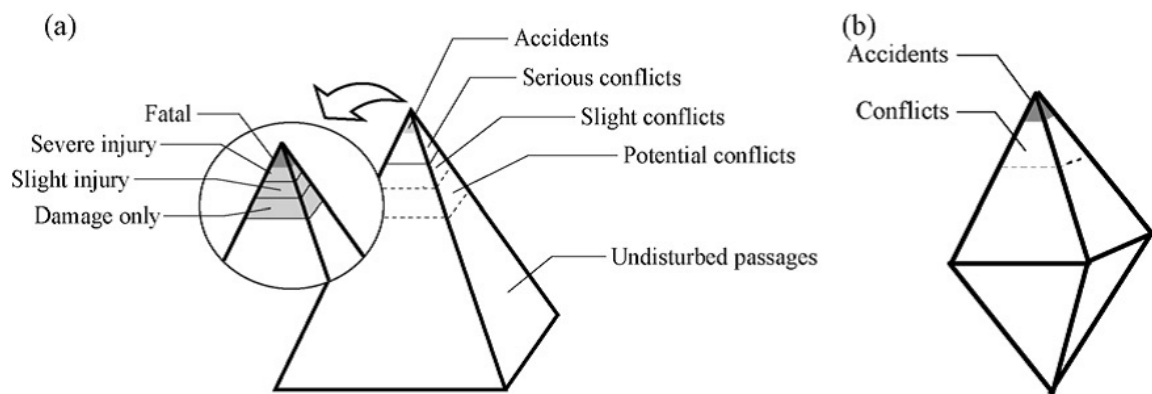

Fig. 1. Relation between traffic events severity (a) pyramid model [12] and (b) diamond model based on the severity hierarchy [22]

The literature suggests various models for expressing the two marginal states of the road safety in the given location based on their frequency, which shows these two extremes: "undisturbed passage" on one hand and "accident" with various severity levels on the other hand (the "traffic continuum"). The modern models are either based on the pyramid model [12] describing the relation between the events severity and frequency, Figure 1 (a), or the diamond model [22], which is based on the severity hierarchy events at a particular site, e.g. an intersection, Figure 1 (b). 


\section{SWEDISH TRAFFIC CONFLICT TECHNIQUE}

The traffic conflict research noted significant development at the Technical University of Lund, Sweden, in the 1970's and 1980's. They developed the traffic conflict observation method here, which has been named the "Swedish Traffic Conflict Technique" according to the country of origin. It focused on situations, in which two road users would collide if neither of them made some kind of an evasive action. The point, in which such evasive action is performed, is recorded by the observer as the "Time-to-Accident" (TA). The TA value along with the conflict speed was used to determine whether the conflict was severe or not [12].

The milestone of its scientific recognition of TCT was the international traffic conflict workshop in Oslo, which accepted the common definition of a traffic conflict and principles of its observation and evaluation [10].

The traffic conflict was jointly defined here as "an observable situation, in which two or more road users approach each other in space and time to such an extent that there is a risk of collision if their movements remain unchanged" [2].

The "International Committee for Traffic Conflict Techniques" (ICTCT) gradually organized the comparative and calibration studies in several countries. The most extensive one was the study focused on severity of identified conflict situations conducted in Malmö in 1983 with participation of 8 foreign teams. The 8 "national" methods of conflict observation and evaluation proved that the differences between them were not significant and that interpretation of the results, as far as the conflict severity is concerned, mainly depends on the severity definition applied The observers agreed on $75 \%$ of identified severe conflicts [9].

\section{RELIABILITY AND VALIDITY OF THE TCT METHODS}

While the interest in TCT using the traffic conflict observation and evaluation was huge, its practical utilization remained limited. This state was the result of the doubts and thus increasing number of questions concerning validity and reliability. And the relatively high price of the input data collection did not support its wider expansion in practice, either.

The TCT method validity is mostly assessed according to the adequate correlation between the observed number of conflicts and accident records. Such understanding originates from the practice applied in the long term, which is based on the safety evaluation according to the accident data [5, page 174]. The American study conducted by [18] proved that the normal study of conflict situations can provide estimates of average frequency of accident occurrence, which are at least as accurate as those based on the historical data. In opinion of other authors [16, page 1], some problems with the validity are definitely caused by inaccurate and insufficiently processed accident data.

Another important issue is also the "process validity", i.e. whether the conflict triggering processes are the same like those, which cause accidents. Based on the data related to TA and speed values, [12] revealed that the conflicts and accidents actually share the same severity allocation and that the accidents generally reached the TA (time-to accident) value below $0.5 \mathrm{sec}$ and the speed of 10 - $20 \mathrm{~km}$ per hour higher than the conflicts.

At the early times of its utilization, reliability of the conflict measurement was based on the assumption that all conflicts must be assessed in terms of the drivers' actions. This resulted in a number of subjective interpretations. But even at that time, if the conflicts are well defined and the observers well trained, the subjective evaluation of conflicts can remain being a source of major differences in results. Video-recordings can provide repeated assessment, however, they do not provide the same quality as the observation by a person present on site does. The observers on site usually have a better opportunity to evaluate based on direct seeing of all events ongoing in parallel than from a limited two-dimensional sequential watching the video-recordings [5, page 176].

The differences between the individual observers in evaluating the severity of an evasive maneuver are, therefore, a subject of frequent criticism of this method. This is the reason why alternative indicators of more objective measurement were proposed, enabling getting a measure on the severity scale proven in time. The most frequent detail of this kind is "Time-to-Collision" (TTC), defined as time required for two vehicles to collide if they continue at their present speed and on the 
same path. If the collision occurs, the TTC value becomes final and decreases in time. The critical value for assessing the conflict is, therefore, the TTC minimum for its duration.
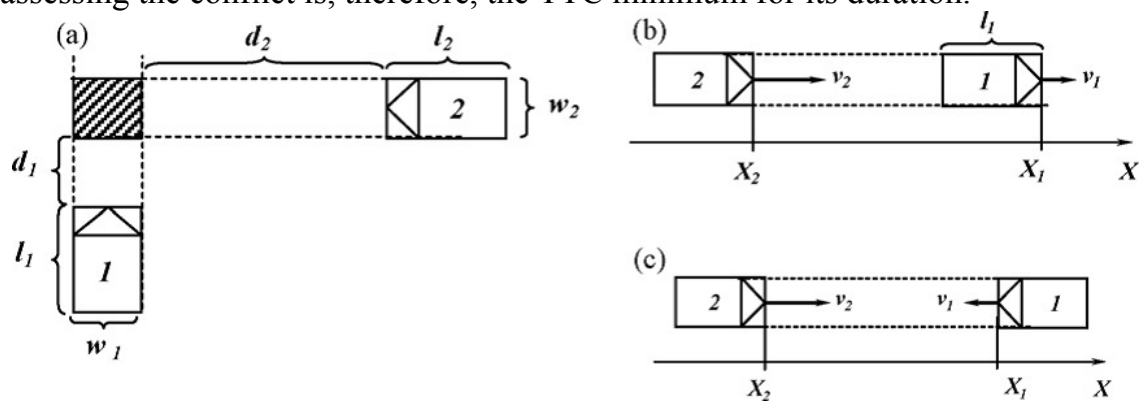

Fig. 2. TTC calculation for perpendicular and parallel trajectories [16].

For the the case of right-angle approach, the Time-to collision (TTC) is calculated using the equation (1).

$$
\begin{array}{lll}
T T C=\frac{d_{2}}{v_{2}}, & \text { if } & d_{1} / v_{1} \leq d_{2} / v_{2} \leq\left(d_{1}+l_{1}+w_{2}\right) / v_{1} \\
T T C=\frac{d_{1}}{v_{1}}, & \text { if } & d_{2} / v_{2} \leq d_{1} / v_{1} \leq\left(d_{2}+l_{2}+w_{1}\right) / v_{2}
\end{array}
$$

Where $d_{1}$ and $d_{2}$ are distances from the fronts of vehicles 1 and 2 , respectively, to the area of intersection $\mathrm{l}_{1}, \mathrm{l}_{2}, \mathrm{w}_{1}, \mathrm{w}_{2}$ are lengths and widths of vehicles 1 and 2 , respectively; $\mathrm{v}_{1}, \mathrm{v}_{2}$ are vehicle speeds (Fig. 2a).

Time-to collision (TTC) is, in the event of rear-end collision is calculated according to equation (2) [17], where X1 and X2 are the position coordinates of front parts of the vehicles 1 and 2 respectively (Fig. $2 b)$.

$$
T T C=\frac{X_{1}-X_{2}-l_{1}}{v_{1}-v_{2}}, \quad \text { if } \quad v_{2} \geq v_{1}
$$

In the event of head-on collision, the previous equation is simplified into equation (3) (Fig.2c).

$$
T T C=\frac{X_{1}-X_{2}}{v_{1}+v_{2}}
$$

Another indicator according to equation (4) used to describe situations where two road users pass a common spatial zone but in different times and thus avoid a collision course and thereby collision is called PET Post-Encroachment-Time (Fig. 3) [1]. PET is used in situations when the collision did not occur, but the time difference of the intersection of the trajectories is found below certain value. [14]

limit
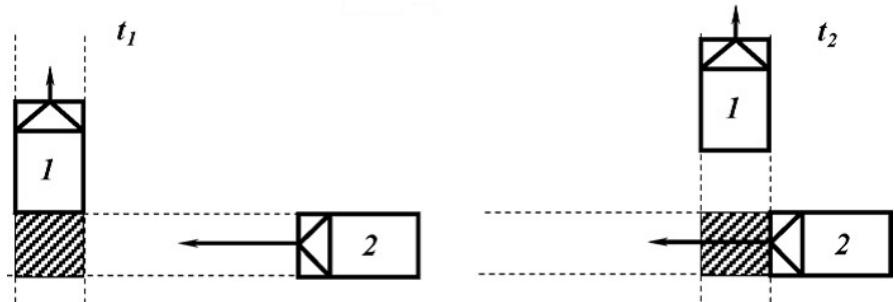
Fig. 3. PET definition [1].

$$
\text { PET }=t_{2}-t_{1}
$$

\section{AUTOMATED ANALYSIS OF VIDEO-RECORDING}

The automated analysis of video-recording is a new technique that has made a huge progress thanks to the fast development of information technologies. The present methods can record and observe more road users of various kinds [14]. The big potential of this method development leads to expansion of the explored area, shortening of the processing time and improvement of the result accuracy. It can be expected to soon provide tools for a detailed description of movements (in coordinates and depending on time) of all road users in the observed area, for instance at the entire intersection. A number of such obtained details have huge potential, but the practical methodology of their processing has not been developed yet. The purpose of further research is to design a theoretical scope for development of a method utilizing the data obtained from the video-recordings. According to [16, page 1 and 2], this is the first attempt to develop a set of indicators, which can describe a fluent process of interactions between the individual road users and relate them to the general safety situation in the subject area.

\section{NEWLY DEVELOPED SAFETY RESEARCH METHODS}

The unique progress of recording technologies and statistical methodologies in the recent years has become the driving development of new safety prediction research and modeling methods in the United States. The new methods based on the data from automated video-recording include:

\subsection{Method of Precise Measurement of Vehicles Interactions}

This method is based on effective and accurate measurement of distance separations between vehicles and time separation between events. It is a promising though yet experimental method that obtains surrogate safety indicators from such measurements with the use of probability causal models [6].

\subsection{Cars Naturalistic Driving Study}

This is essentially new complex approach to researching circumstances, which mark occurrence of accidents. The method was proposed based on the progress in development of advanced technical equipment enabling collection, storage and analysis of huge amount of data with the use of state of the art devices, which are getting smaller and smaller. Observation was performed during normal everyday driving of vehicles equipped with the devices, which unobtrusively and gently record the vehicle maneuvering (such as speed, acceleration/deceleration and driving direction), as well as the driver's behavior (focus of eyes, head and arm movements) and external conditions, such as road characteristics, traffic density, weather, etc.). The experiment lasted for 12 to 13 months. More than 2 million kilometers were driven and 70 accidents of various severity occurred, 761 near-accidents and 8295 conflicts recorded. Huge amount of data was collected (6 terabytes). The experiment provided extraordinarily valuable details of relations between the driver, road, vehicle, weather and traffic situation. The data was processed by an advanced system enabling concurrent approach of several evaluators [11].

\section{CONCLUSIONS TO BE APPLIED IN PRACTICE}

Following adoption of the "Directive of the European Parliament and of the European Council No. 2008/96/EC on road infrastructure safety management" [23], the traffic safety evaluation according to the traffic conflicts got a new impulse. The related Act No. 13/1997 Coll. on roads obliges the road operators to evaluate the traffic safety in form of audit on a regular basis. 


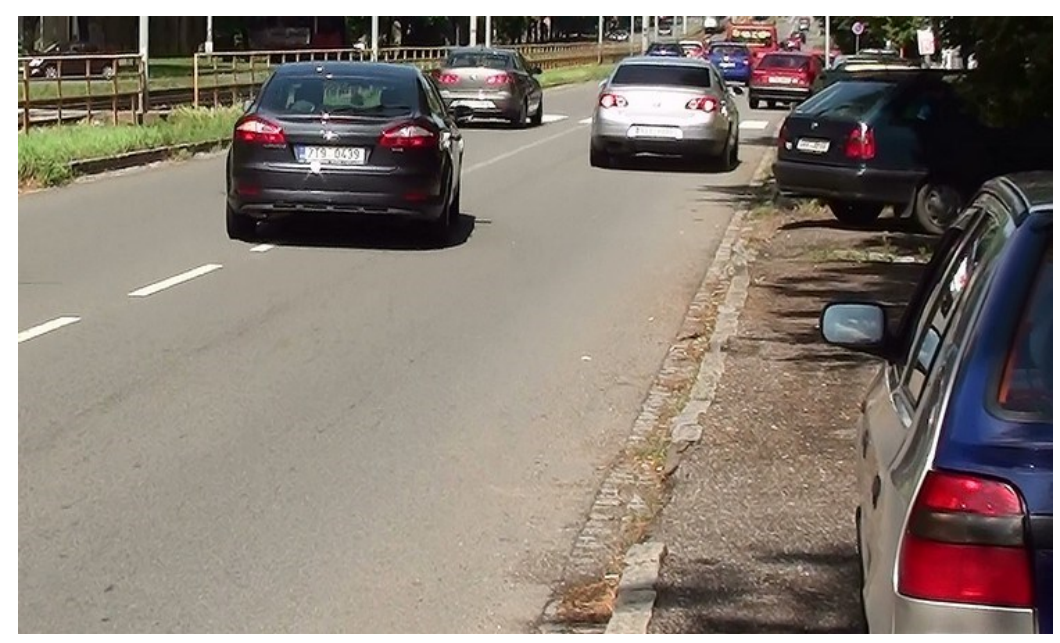

Fig.4. Traffic conflict record. Vehicle decelerating because of parking maneuver is limiting the following vehicle, that had to undertake a severe evasive action [23].

There are two TCT methods used in the Czech Republic. The VSB-Technical University of Ostrava, to a large extent, uses the video-recording method according to [8] for observing and evaluating the traffic behavior at intersections, pedestrian crossings, cycling or rail crossings, mass transportation stops, etc. The Czech Technical University (CVUT) uses a similar methodology that is based on evaluation by trained observers on site [19]. Regarding the fact that the automatic videorecording method is still in the stage of development, use of some procedures enabling semiautomatic processing of the video-recording shall be considered in order to improve efficiency of this periodical control. Therefore, borrowed software enabling semi-automatic processing of the videorecording for the study of effect of parallel parking along roads on the road safety will be tested as a part of the project [22].

\section{ACKNOWLEDGMENT}

This paper was supported from financial resources of concept development of science, research and innovations for 2012 which was allocated to VŠB-TU Ostrava by the Ministry of Education, Youth and Sports of the Czech Republic [23].

\section{REFERENCES}

[1] Allen, B.L., Shin, B.T., Cooper, P.J., 1977. Analysis of Traffic Conflicts and Collisions. Department of Civil engineering, Mc. Master University.

[2] Amundsen, F.H., Hydén, C. 1977. Proceedings: First Workshop on Traffic Conflicts. Institute of Transport Economics, Oslo, Norway.

[3] Archer, J. 2001. Traffic Conflict Technique. Historical to current State-of-the-Art. Institutionen för Infrastruktur KTH, Stockholm, September 2001, str. 2-3.

[4] Archer, J. 2005. Indicators for traffic safety assessment and prediction and their application in micro-simulation modelling: A study of urban and suburban intersetions. Doctoral Dissertation. Royal Institute of Technology, Stockholm, ISBN 91-7323-119-3.

[5] Chin, H.C., Quek, S.T. 1977. Measurement of Traffic Conflicts, Safety Science, Vol. 26, No.3, pp. 169-187. 
[6] Davis, G., Hourdos, J., Xiong, H., 2008. Outline of a causal theory of traffic conflicts and collisions., Proceedings of 87th Anual TRB meeting, Wahsington, DC.

[7] Folprecht, J., 2000. Dosavadní vývoj a perspektivy metody sledování a hodnocení konfliktních situací v silničním provozu.. Silniční obzor 61, pp. 39-44.

[8] Folprecht, J., Křivda, V., 2006. Organizace a řízení dopravy I. Ostrava. VŠB-TU Ostrava, 2006, 158 s. ISBN 80-248-1030-1.

[9] Grayson, G.B, Hydén, C., Kraay, J.H., Muhlrad, N., Oppe, S. 1984. The Malmö Study. A Calibration of Traffic Conflict Techniques. SWOV Report R-84-12, Leidschendam.

[10] Gstalter, H., Fastenmeier, W. Thirty years of traffic safety research: A personal retrospective of concepts and methods. In: Proceedings of 20th ICTCT Workshop., Session IVMethodological Issues.

[11] Guo, F., Klauer, S.G., Hankey, J.M., Dingus, T.A., 2010. Near-crashes as crash surrogate for naturalistic driving studies. Transportation Research Record, 2147, pp. 64-66.

[12] Hydén, C., 1987. The development of a method for traffic safety evaluation: the Swedish traffic conflict technique. Doctoral Thesis, Lund University, Department of Traffic Planning and Engineering.

[13] Křivda, V., 2011. Video-Analysis of Conflict Situations on Selected Roundabouts in the Czech Republic. Communications. Žilina: University of Žilina, 2011, roč. 13, č. 3, s. 77-82. ISSN 1335-4205.

[14] Laureshyn, A., 2010. Application of automated videoanalysis to road user behaviour. Doctoral Thesis. Bulletin-Lund Universitet. ISBN 978-91-628-8003-3.

[15] Laureshyn, A., Ardö, H., Jonsson, T., Svensson, A., 2009. Application of automated video analysis for behavioural studies: concept and experience. IET Intelligent Transport Systems 3 (3), 345-357.

[16] Laureshyn, A., Svensson, A., Hydén, C., 2010. Evaluation of traffic safety, based on microlevel behavioural data. Theoretical framework and first implementation. Accident Analysis and Prevention (2010), doi: 10.1016/j.aap.2010.03.021, Elsevier Ltd.

[17] Minderhoud, M.M., Bovy, P.H.L., 2001. Extended time-to-collision measures for road traffic safety assessment. Accident Analysis and Prevention 33, pp. 89-97.

[18] Migletz, D.J., Glauz, W.D., Bauer, K.M., 1985. Relationship between traffic conflicts and accidents. Report No.: FHWA/RD-84/042. US Department of Transportation, Federal Higway Administration.

[19] Older, S.J., Spicer, B. (1976) Traffic conflicts - A development in accident research. Human Factors, 18, 335-350.

[20] Slabý, P., Kocourek, J., 2006. Metoda sledování dopravních konfliktů. Silniční obzor 67: 275 278.

[21] Perkins, S.R., Harris, J.I., 1968. Traffic conflicts characteristics: Accident Potential at intersections. Highway Research Record, 225, 35-43.

[22] Svensson, A., 1998. A method for analysing the traffic process in a safety perspective. Doctoral Thesis, University of Lund, Lund Institute of Technology, Department of Traffic Planning and Engineering.

[23] Křivda, V. a kol. Vliv podélného parkování na bezpečnost a kapacitu pozemní komunikace v mezikřižovatkovém úseku. Project supported from financial resources of concept development of science, research and innovations for 2012 which was allocated to VŠB-TU Ostrava 
by the Ministry of Education, Youth and Sports of the Czech Republic. Ostrava: VŠB-TU Ostrava, Faculty of Civil Engineering. 2012 (in solution).

[24] Směrnice Evropského parlamentu a Rady 2008/96/ES ze dne 19. 11. 2008 o řízení bezpečnosti silniční infrastruktury (http://eur-lex.europa.eu/LexUriServ.do). 